\title{
Effectiveness of a locally developed ethephon formulation on yield and related latex physiological factors of Hevea brasiliensis
}

\author{
L T B K Fernando*, K V V S Kudaligama*, T H P S Fernando*, \\ W G D Lakmini**, H P P S Somasiri***, N P S N Karunarathne*, \\ K M E P Fernando****, A P Attanayaka*, V H L Rodrigo* and P Seneviratne*
}

* Rubber Research Institute of Sri Lanka, Dartonfield, Agalawatta, Sri Lanka

** Department of Crop Science, Faculty of Agriculture, University of Ruhuna,

Kamburupitiya, Sri Lanka

*** Industrial Technology Institute, Baudhaloka Mawatha, Colombo 7, Sri Lanka

**** University of Sri Jayawardenapura, Gangodawila, Nugegoda, Sri Lanka

\begin{abstract}
Ethephon is an essential agrochemical in low intensity harvesting of rubber (Hevea brasiliensis). Currently the total requirement for rubber industry is being imported in ready-mixed form adding a considerable cost to the plantations. Therefore, a new ethephon formulation was developed locally and the present study aimed to assess its effectiveness under Sri Lankan condition.

The newly developed ethephon formulation was tested against a commercially available formulation with a small-scale field trial. No significant variation was observed in sucrose availability in laticifers with the new ethephon formulation. Significantly higher thiol and lower inorganic phosphorous contents of latex in trees may ensure long-term sustainability of the new ethephon formulation as a yield stimulant in rubber. Average dry rubber content of latex and latex volume obtained from a tree was comparable with both formulations. Accordingly, dry rubber yield resulted from trees applied with new ethephon formulation was comparable with the existing formulation and average values were $83.22 \mathrm{~g}$ and $86.67 \mathrm{~g}$, respectively for new and existing formulations.
\end{abstract}

Key words: 2-choloroethylphosphonic acid, ethephon, exploitation, Hevea, low intensity harvesting, rubber, stimulation

\section{Introduction}

Stimulation based low intensity harvesting (LIH) systems designed with various combinations of cut lengths, frequency of tapping and stimulation techniques are accepted by the growers as modern exploitation techniques to overcome constrains such as high cost of production (COP), lack of skilled harvesters and high bark consumption rates in rubber plantations. Suitable stimulation protocol is used with $\mathrm{LIH}$ systems to overcome low yields due to lowering the harvesting intensity thus to 
achieve comparable yields to that of conventional tapping i.e. $\mathrm{S} / 2 \mathrm{~d} 2$ system (Gao et al., 2018). A wide spectrum of chemical compounds including ethylene generating compounds, auxins, auxin analogues, herbicides and inorganic salts had been tried as yield stimulants from the beginning of rubber plantation industry. Few of them were ethylene generators while others appeared to be more or less phytotoxic which may induce endogenous ethylene production. Ethephon (2-chloroethylphosphonic acid) was found superior to all other chemicals and even today ethephon is the only stimulant used in commercial application. Hence, nowadays ethephon has become an essential agrochemical used in harvesting of rubber. Ethephon stimulation based LIH systems enhance the sustainability of rubber farming with a better income to the harvester and lower cost of production (COP) to the management.

Ethephon is a plant growth regulator with systemic properties, penetrates into the plant tissues, translocate and in the presence of water. It progressively decomposed to ethylene (Tseng et al., 2000), which is a kind of plant hormone that affects the biochemical and physiological status of the tree resulting in high yields.

It is a whitish solid readily soluble in aqueous solutions and stable below $\mathrm{pH}$ 3.5 (Anon., 1987) and could not be applied on trees as it is. So it is usually mixed with an inert material i.e. methyl cellulose, starch, palm oil or a mixture of such materials to make it more viscous enabling easy application on bark of tree whilst increasing the slow release properties.

Stimulation effect of ethephon depends on the length of cut and frequency of tapping or combination of them (Njukeng et al., 2011). A large number of low intensity systems have been used with different levels of ethephon in many rubber growing countries (Karunaichamy et al., 2001; Kewi \& Sivakumaran, 1994; Rodrigo et al., 2011; Xuehua et al., 2004). Judicious application of ethephon with correct harvesting systems may only give long term sustainable yields.

In Sri Lanka ethephon based low intensity harvesting systems i.e. $\mathrm{S} / 2 \mathrm{~d} 3$ (Nugawela et al., 2000), S/2 d4 (Rodrigo et al., 2011) and S/4 d3 (Rodrigo et al., 2012) have been recommended and currently adopted in plantations in an increasing trend. Total requirement of the ethephon to Sri Lankan rubber plantation industry is presently imported and marketed at a price of about LKR 1000 per kg. Some Regional Plantation Companies import 3 to 6 MT of ethephon annually (personal communication) and CIF value of such amount is about 1-2 Mn LKR (1USD = 180 LKR). In view of minimizing the cost involved, a formulation of ethephon was developed locally and the present study aimed to assess its suitability under field conditions in Sri Lankan rubber plantations.

\section{Materials and Method}

A new formulation with $2.5 \%$ ethephon has been developed by Rubber Research Institute of Sri Lanka by using concentrated ethephon available in the 
market. Mixture of carbohydrate derivatives (methyl cellulose, starch and xanthan gum) were used to increase the viscosity of mixture thus improve the slow release properties of the new formulation. Organic acids were used to reduce the $\mathrm{pH}$ to prevent decomposing of ethephon. By using motorized blender all the ingredients were thoroughly mixed to give about $1200 \mathrm{cP}$ viscosity and final ethephon concentration of the mixture was set to $2.5 \% \pm 0.1 \%$.

Rainguarded monoclonal mature rubber field replanted in 2011 with RRIC 121 in Gallewatta Division of Dartonfield Estate was selected for testing the efficacy of new ethephon formulation developed by the Rubber Research Institute of Sri Lanka. Ethephon-Plus currently available water-based commercial ethephon mixture in the local market was used for comparison as the control. Both treatments were tested using a randomized complete block design (RCBD) with three replicates comprising 10 trees in each plot. Efficacy was tested using recommended protocol for $\mathrm{S} / 2 \mathrm{~d} 4$ system in Sri Lanka with application of $2.5 \%$ ethephon, monthly. The amount applied per tree per application was $1.6 \mathrm{~g}$ (Rodrigo et al., 2011).

Analyses of latex samples were done in each tapping day. Latex was collected into vessels immersed in ice between $5^{\text {th }}$ and the $35^{\text {th }}$ minutes after tapping and immediately taken to the laboratory for analysis. Extractions were prepared by coagulating the latex samples with $2.5 \%$ tricloroacetic acid (TCA). Standard test methods were used for analysis of sucrose (Scott and Melvin, 1953), inorganic phosphorous (Taussky and Shorr, 1953) and thiol (Boyne and Ellman, 1972). Standard laboratory method (Anon., 1984) was used to analyse dry rubber content of latex. Plugging index was determined by measuring the initial flow rate and total volume of latex obtained as described by Milford et al. (1969). Applied area of the bark has been frequently observed for any fungal or bacterial growth.

Performance of the new formulation was statistically compared with the existing formulation by performing a paired t-test for each variable tested using Genstat $16^{\text {th }}$ edition.

\section{Results and Discussion}

Generally, the stimulants are known to enhance yield by increasing latex regeneration, flow rate and duration of latex flow (Lacrotte et al., 1985). Physiological parameters of latex are associated with either latex regeneration or latex flow or both effects. Ultimately the productivity of the tree is a combined effect of all these factors. In plants, the sucrose produced by photosynthesis is finally the basic molecule in all synthesis. In Hevea, sucrose is metabolized into polyisoprene in the latisifers cells (Bealing, 1976; Tseng et al., 2000). Sugar content in laticifers positively correlates with isoprene production (Lacrotte et al., 1985; Mesquita et al., 2006).

Average sucrose content of latex of trees applied with new and existing formulations were $3.47 \mathrm{mM}$ and 3.97 $\mathrm{mM}$, respectively and statistically comparable. In both formulations, latex sucrose content increased immediately 
after ethephon application and tended to decrease with time (Fig. 1a). The massive outflow of latex induced by stimulation leads necessarily to an increase in the anabolic activities in the cells and specially biosynthesis of rubber and proteins involved in this renewal (Mesquita et al., 2006). Tupy (1973) explained that rise in latex $\mathrm{pH}$ after stimulation results in an increase in invertase activity which, intensify sucrose mobilization and transported towards vessels where regeneration of latex and metabolism activated. Increase of the activity of invertase; the key enzyme of glycolysis leads to increased production of pyruvate and ATP. Availability of these molecules enhances mevalonate production and ultimately the rubber biosynthesis (d'Auzac, 1989). Latex thiols consist of cysteine, methionine and glutathionine which are able to neutralize various forms of reactive oxygen species that harms membranes of latex organelles thus promoting colloidal stability and flow of latex hence, directly correlate with production (De Costa et al., 2006; Jacob et al., 1986). Variation of latex thiol content with application of new formulation showed an increase with time (Fig. 1b) and average of trees applied with new formulation was $230 \%$ higher than that with existing formulation. This ability of the new formulation is highly favorable to remove reactive oxygen species evolved during rubber production and may lower the incidence of tapping panel dryness. Latex inorganic phosphorous may reflect its energy metabolism and significantly correlates with latex production in trees (Eschbach et al., 1984). Ethephon stimulation activates the laticifer metabolism and also increases the inorganic phosphorous content (d'Auzac and Pujarniscle, 1959). Both formulations showed a similar pattern of variation in latex inorganic phosphorous content. However, in trees applied with the new ethephon formulation, latex inorganic phosphorous content was significantly lower than that with the existing ethephon formulation (Fig. 1c). This reveals that energy needed for latex regeneration is comparatively lower in trees applied with new ethephon formulation.

Ethylene is thought to enhance yield by delaying plugging of latex vessels (Emuedo et al., 2017; Gao et al., 2018) and enhancing both initial flow rate (de Jonge, 1955) and duration of flow (Coupe, et al., 1976 \&1977; Coupe \& d'Auzac, 1974). Researchers commonly accept that the increase of yield is mainly due to the extension in drainage area (Pakianathan et al., 1976; Ribaillier \& d'Auzac, 1970). 


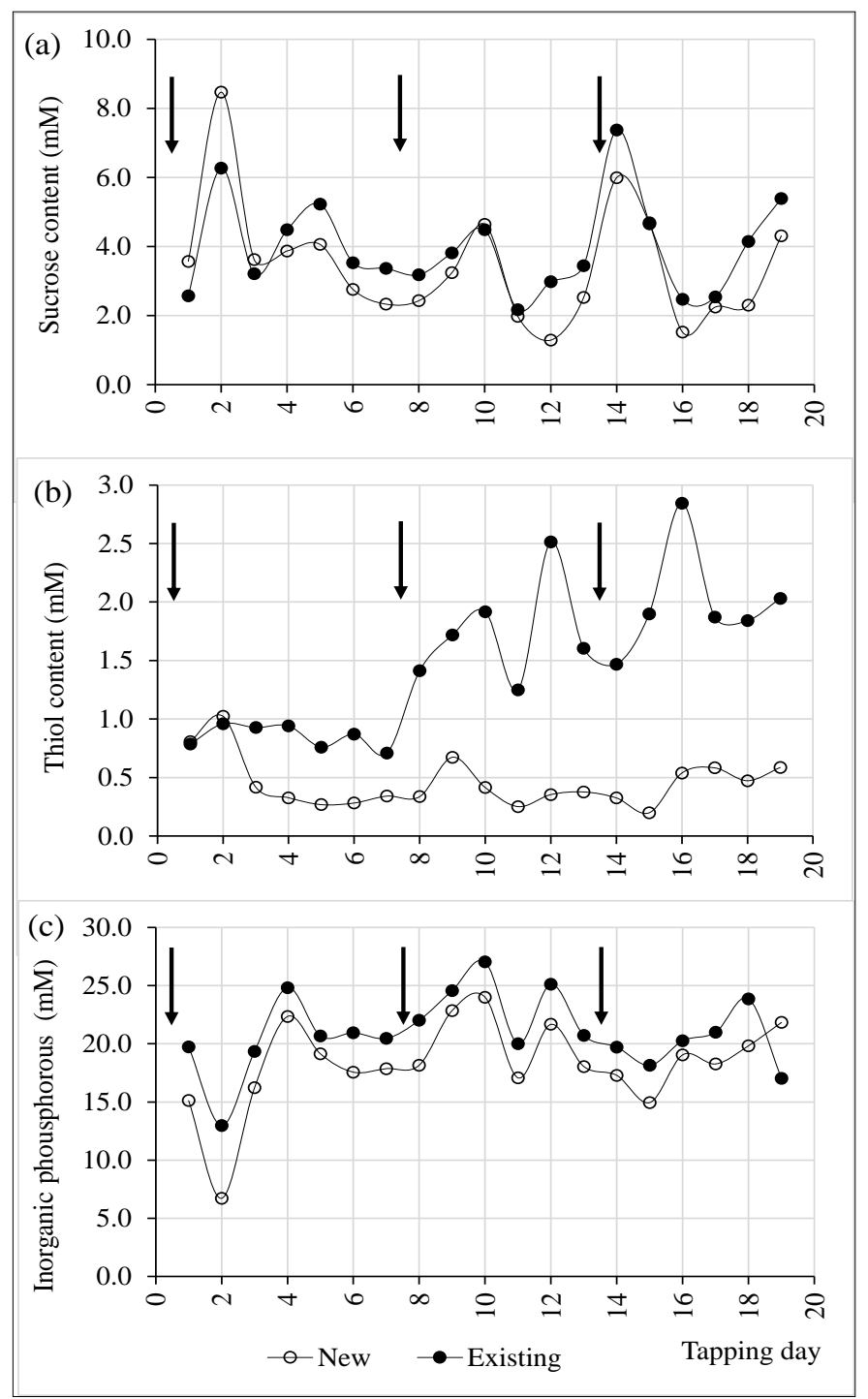

Fig. 1. Variation of latex (a). sucrose, (b). thiol and (c). inorganic phosphorous contents of trees stimulated with two ethephon formulations (Time of ethephon application is indicated by arrows)

Duration of latex flow with existing ethephon formulation was significantly lower than that with new formulation. However, the average difference is 19 min. (Fig. 2a). Immediately after stimulation, average latex flow duration extended to $3.8 \mathrm{hrs}$ and $3.7 \mathrm{hrs}$ with new and existing formulations, respectively. 
At the end of first month, the flow duration decreased up to $2.4 \mathrm{hrs}$ and 2.0 hrs, respectively (Fig. 2a). Average initial flow rate of trees applied with new ethephon showed statistically significant decrease over existing formulation (Fig. $2 b$ ). Respective average values of new and existing formulations were 4.32 $\mathrm{ml} / \mathrm{min}$. and $4.74 \mathrm{ml} / \mathrm{min}$. (Fig. 2a). Plugging index of trees showed a significant difference among two ethephon formulations with averages of 1.96 and 2.36 with new and existing formulations, respectively (Fig. 2c).
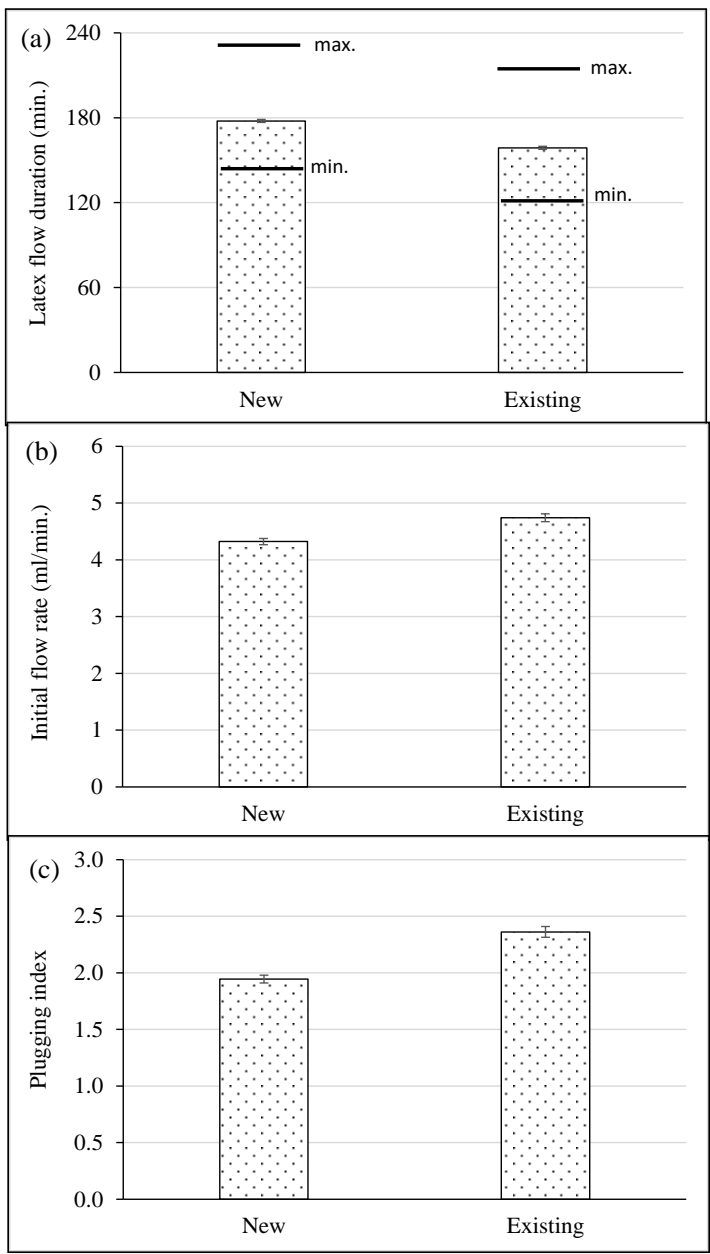

Fig. 2. Average (a). latex flow duration, (b). initial flow rate and (c). plugging index of trees stimulated with two ethephon formulations 
L T B K Fernando et al.

Pattern of variation of latex volume of trees applied with new ethephon formulation was more or less similar to the existing formulation. With both formulations latex volume showed a significant increase after ethephon application and gradually decreased with time. Average daily volume of latex per tree with application of new and existing formulations was $208 \mathrm{ml}$ and $222 \mathrm{ml}$, respectively and statistically comparable (Fig. 3a). Immediately after stimulation, observed maximum latex volumes with new and existing formulation were 380 $\mathrm{ml}$ and $433 \mathrm{ml}$, respectively whilst minimum values i.e. $112 \mathrm{ml}$ and $120 \mathrm{ml}$ observed towards the next application (Fig. 3a). Irrespective of the formulation, average daily volume of a tree increased by $155 \%$, immediately after ethephon application.

With application of ethephon, dry rubber content (DRC) tended to decrease immediately and then increased towards the next application. The DRC of latex varied in a similar pattern with both ethephon formulations and significant variation has not been observed among two formulations (Fig. 3b). However, throughout the period, DRC did not fall below $35 \%$ at any instance with both formulations (Fig. 3b).

Dry rubber yield obtained from a tree with both ethephon formulations was statistically comparable. Average daily dry rubber yield of a tree was $83.22 \mathrm{~g}$ and $86.67 \mathrm{~g}$, respectively with new and existing formulations (Fig. 3c). After stimulation, dry rubber yield with existing formulation increased to a value around $162 \mathrm{~g} /$ tree and yield with new formulation was $149 \mathrm{~g} /$ tree. At the end of first month towards next ethephon round, dry rubber yield decreased to $48 \mathrm{~g} /$ tree with both formulations.

During the period of investigations any fungal or bacterial growths have not been observed in ethephon applied area of the bark confirms that there is no effect on bark of tree.

Results revealed that new ethephon formulation is capable in resulting comparable yields to the existing formulation. Latex DRC and volume of latex did not show any significant variation among the two formulations. Significantly lower inorganic phosphorous content with new formulation indicates lower energy requirement in metabolic process of biosynthesis. So far, a stimulant capable in increasing similar higher amount of latex thiol has not been reported. Increased thiol content together with low inorganic phosphorous content of latex in trees applied with the new ethephon formulation may ensure long term sustainability of health of rubber tree. With the new formulation, initial flow rate increased significantly and comparatively higher plugging index in existing ethephon formulation applied trees lower the latex flow time than in the trees applied with the new formulation. Although, the duration of flow has extended with the new formulation, it would not affect significantly on time taken for commercial latex harvesting as the difference is less than 20 minutes. According to the average daily yield per tree observed, yield that could be obtained from a tree (@80 tapping days/yr under S/2 d4 system) with new and existing formulations accounted for 
$6.76 \mathrm{~kg}$ and $7.00 \mathrm{~kg}$ and corresponds to productivity values of $2,702 \mathrm{~kg} / \mathrm{ha} / \mathrm{yr}$ and 2,799 kg/ha/yr (@ tapping stand of 400 trees/ha), respectively. Annually about $30 \mathrm{MT}$ of $2.5 \%$ formulated ethephon is imported for rubber plantations in Sri Lanka. If we could produce this quantity locally by importing active ingredient in
$40 \%$ concentration, the quantity to be imported will reduce by sixteen times. Further investigations are needed to assess long- term sustainability of the new ethephon formulation with advanced features developed by the Rubber Research Institute.
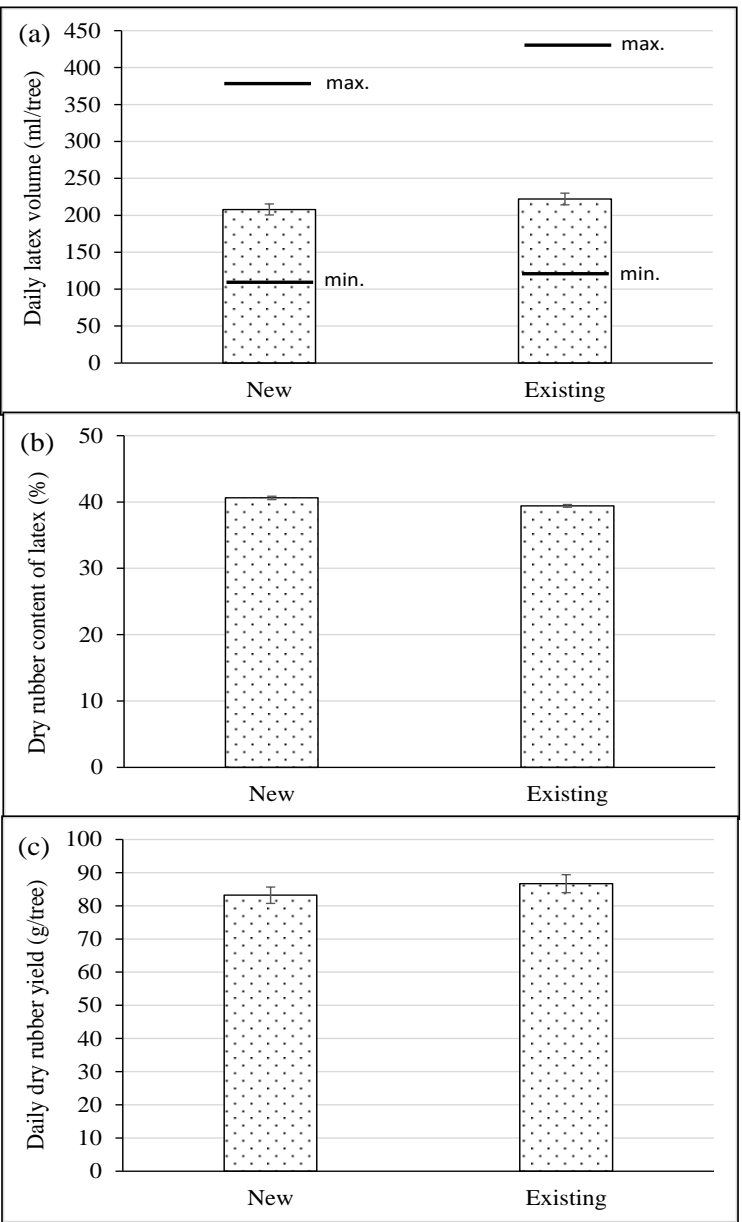

Fig. 3. Average (a). latex volume, (b). latex dry rubber content and (c). daily dry rubber yield of trees stimulated with two ethephon formulations 


\section{Acknowledgement}

National Science Foundation of Sri Lanka is greatly acknowledged for the financial support given under research grant No: RG/2017/AG/1. Support of staff of Biochemistry and Physiology Department, Senior Manager, Dartonfield Estate and his staff are also acknowledged for the support given for the study.

\section{References}

Anon. (1984). ISO Standards Hand Book 22. Volume 1 and 2. International Standard Organization.

Anon. (1987). The Agrochemicals Handbook. 2nd ed. A179/Aug 87. Royal Society of Chemistry. Unwin Brothers Limited, Surrey, U.K.

Bealing, F J (1976). Quantitative aspects of latex metabolism: Possible involvement of precursors other than sucrose in the biosynthesis of Hevea rubber. Proceedings of the International Rubber Conference, Kuala Lumpur, Malaysia. pp.543-563.

Boyne, A F and Ellman, G L (1972). A methodology for analysis of tissue sulfhydryl components. Analytical Biochemistry 46, 639-653.

Coupe, M and d'Auzac, J (1974). Actions de l'acide chloro-2-ethyl-phosphonique (Ethrel) sur les polysomes du latex d' Hevea brasiliensis (Kunth) Muell. Arg. Physiologie Vegetale 12, 1.

Coupe, M, Lambert, C and d'Auzac, J (1976). Etude comparative des polyribosomes du latex d'Hevea sons l'action de l'ethrel et d'antres produits augmentant l'ecoulement du latex. Physiologie Vegetale 14, 391.

Coupe, M, Lambert, C Primot, L and d'Auzac, J (1977). Cinetique d'action de l'acide 2-chloroethylphosphonique sur les poly-ribosomes du latex d'Hevea brasiliensis. Phytochemistry 16, 1133.

d'Auzac, J (1989). The hormonal stimulation of latex yield. In: Physiology of Rubber Tree Latex. 289-342 (Eds. J d'Auzac, J L Jacob and H Chrestin), CRC Press, Florida.

d'Auzac, J and Pujarniscle, S (1959). Sur les différentes formes de phosphore présentes dans le latex d' Hevea. Revue Générale du Caoutchouc et des Plastiques 36, 862-870.

De Costa, C M, Dos Santos, R C C and Lima, E S (2006). A simple automated procedure for thiol measurement in human serum samples. Brazilian Journal of Pathology and Laboratory Medicine 42(5), 345-350.

de Jonge, P (1955). Stimulation of yield in Hevea brasiliensis. III, Further observation of the effect of yield stimulation. Journal of Rubber Research Institute of Malaya 14, 383.

Emuedo, O A, Omokhafe, K O, Ohikhena, F U, Uzunuigbe, E O, Uwumarongie, A M D, Chukwuka, A N, Ugiagbe Ekue, U, Omorogbe, J A and Ehiwe, D (2017). Basal studies of Mortex as a latex yield stimulant of Hevea brasiliensis. Journal of Scientific and Engineering Research 4(12), 472-476.

Eschbach, J M, Roussel, D, Van de Sype, H and Jacob, J L (1984). Relationships between yield and clonal physiological characteristics of latex from Hevea brasiliensis. Physiologie Vegetale 22, 295-304.

Gao, L, Sun, Y, Wu1, M, Wang, D, Wei1, J, Wu1, B, Wang, G, Wu1, W, Jin, $\mathrm{X}$, Wang, X and He, P (2018). Physiological and proteomic analyses of molybdenumand ethylene-responsive mechanisms in rubber latex. Frontiers in Plant Science 9 , $1-15$.

Jacob, J L, Prevot, J C and Vidal, A (1986). Evidence of an alkaline inorganic 
New ethephon formulation for stimulation of rubber

pyrophosphatase activity in the cytosol of Hevea brasiliensis latex. Partial purification and some characteristics of this enzyme, presented at International Meeting on Physiology and Exploitation, International Rubber Research Development Board, Hainan, China, pp.1-20.

Karunaichamy, K, Vijayakumar, K R, Thomas, K U, Rajgopal, R and Anil Kumar, D (2001). Response of rubber trees (Hevea brasilienses Mull. Arg. clone RRII 105) to Low Frequency Tapping (LFT) systems. Indian Journal of Natural Rubber Research 14 (2), 7989.

Kewi, Chong and Sivakumaran, S (1994). Performance of Low-Frequency tapping systems. Proceedings of the Workshop of the Exploitation Technologies to Address Current Labour Problems in the Rubber Industry. December, 1994, Kuala Lumpur, Malaysia, pp.47-67.

Lacrotte, R, Van de Sype, H and Chrestin, H (1985). Ethylene influence on the use of exogenous sucrose by the laticiferous cell in Hevea brasiliensis. Proposition for action mechanism. Physiologie Vegetale 23, 187-198.

Mesquita, A C, Oliveira, L E M de, Mazzafera, P and Delú-Filho, N (2006). Anatomical characteristics and enzymes of the sucrose metabolism and their relationship with latex yield in the rubber tree (Hevea brasiliensis Muell. Arg.). Brazilian Journal Plant Physiology 18, 263-268.

Milford, G F J, Paardekooper, E C, and Ho, C Y (1969). Latex vessel plugging its importance to yield and clonal behaviour. Journal of the Rubber Research Institute of Malaya 21, 274-282.

Njukeng, J N, Muenyi, P M, Ngane, B K and Ehabe, E E (2011). Ethephon stimulation and yield response of some Hevea clones in the humid forests of South West
Cameroon. International Journal of Agronomy 2011, 1-5.

Nugawela, A, Peries, M R C, Wijesekera, S and Samarasekera, R K (2000). Evaluation of $d / 3$ tapping with stimulation to alleviate problems related to $d / 2$ tapping of Hevea. Journal of the Rubber Research Institute of Sri Lanka 83, 49-61.

Pakianathan S W, Wain, R L and Ng, E K (1976). Studies on displacement area on tapping in mature Hevea trees. In: Proceedings of International Rubber Conference 1975 (II), 225-246.

Ribaillier, D and d'Auzac J (1970). Nouvelles perspectives de stimulation hormonale de la production chez l'Hevea brasiliensis. Revue Générale $d u$ Caoutchouc et des Plastiques 47, 433.

Rodrigo, V H L, Kudaligama, K V V S, Fernando, K M E P and Yapa, P A J (2011). Harvesting the rubber tree once in four days; a solution to current issues in the rubber industry in Sri Lanka. Journal of the Rubber Research Institute of Sri Lanka 91, 15-35.

Rodrigo, V H L, Kudaligama, K V V S, Fernando, K M E P and Yapa, P A J (2012). Replacing traditional half spiral cut by a quarter cut with ethephon; a simple approach to solve current issues related to latex harvesting in rubber industry. Journal of National Science Foundation of Sri Lanka 40 (4), 283-291.

Scott, T A and Melvin E H (1953). Determination of dextran with anthrone. Analytical Chemistry 25 (11), 1656-1661.

Taussky, H H and Shorr, E (1953). A microcolourimetric method for the determination of inorganic phosphorous. Journal of Biological Chemistry 202, 675-685.

Tseng, S, Chang, P and Chou, S (2000). A rapid and simple method for the determination of ethephon residue in agricultural products by GC with 
L T B K Fernando et al.

headspace sampling. Journal of Food and Drug Analysis 8 (3), 213-217.

Tupy, J (1973). The level and distribution pattern of latex sucrose along the trunk of Hevea brasiliensis, as affected the sink region induced by latex tapping. Physiologie Vegetale 11, 1.

Xuehua, L U O, Yunqing, L I U, Xiujuan, C A I, Juqun, $\mathrm{W} \mathrm{U}$ and Bixia, $\mathrm{Z} \mathrm{H} \mathrm{O} \mathrm{U}$ (2004). Effect of different tapping systems on the mineral nutrient of latex total solids of RRIM 600 tree.
Proceedings of the International Rubber Research and Development Board Conference, 7-8 September 2004, Kunming International Convention \& Exhibition Center, China. pp. 8.

Address for correspondence: Dr (Mrs) K V V S Kudaligama, Head, Biochemistry \& Physiology Dept., Rubber Research Institute of Sri Lanka, Dartonfield, Agalawatta, Sri Lanka,

e-mail: kudaligama.rrisl@gmail.com 